\title{
Effect Size Model Pembelajaran Visualization Auditory Kinestetic (VAK) Terhadap Hasil Belajar IPA di Sekolah Dasar
}

\author{
Asri Mulyani ${ }^{1 *}$, Anak Agung Gede Agung ${ }^{2}$, I Nyoman Laba Jayanta ${ }^{3}$ (iD \\ 1,2,3 Program Studi Pendidikan Guru Sekolah Dasar, Universitas Pendidikan Ganesha, Singaraja, Indonesia \\ *Corresponding author: asrimulyaniahmad@gmail.com
}

\begin{abstract}
Abstrak
Belum adanya penelitian terbaru yang mengkaji hasil-hasil penelitian model pembelajaran Visualization Auditory Kinestetic terhadap hasil belajar IPA di tingkat sekolah dasar. Penelitian ini bertujuan menganalisis besar pengaruh model pembelajaran Visual Auditori Kinestetik (VAK) terhadap hasil belajar IPA di SD. Metode yang digunakan yaitu metaanalisis review naratif atau review sistematik dengan menganalisis hasil-hasil penelitian yang telah dipublikasikan secara nasional yang berkaitan dengan penggunaa model Visual Auditori Kinestetik terhadap hasil belajar IPA di SD. Sampel analisis adalah lima buah jurnal yang telah diterbitkan pada rentang tahun 2013-2020, yang membahas penulisan eksperimen dengan menggunakan model Visual Auditori Kinestetik terhadap hasil belajar IPA. Pendekatan yang digunakan adalalah deskriptif kuantitatif, yaitu menghitung effect size dengan mengindentifikasi mean, standar devisi, dan varian dari perhitungan uji-t. Instrument penulisan berupa lembar pengkodean yang merangkum data dan informasi jurnal. Berdasarkan hasil analisis pengaruh secara keseluruhan didapatkan nilai rata-rata besar pengaruh sebesar 3,67 yang berarti dalam kategori efek besar. Temuan analisis juga menunjukan bahwa model pembelajaran Visual Auditori Kinestetik memberikan pengaruh yang efektif dilihat dari segi wilayah dan variable terikat serta media pembelajaran yang digunakan. Pada setiap artikel yang telah dianalisis effect size nya terdapat perbedaan hasil pada model pembelajaran Visual Auditori Kinestetik yang berbantuan media pembelajaran dengan yang tidak berbantuan media pembelajaran tetapi secara keseuruhan effect size dari peneitian ini menunjukan kesimpulan bahwa model pembelajaran Visual Auditori Kinestetik memberikan pengaruh yang besar terhadap hasil belajar IPA di SD.
\end{abstract}

Kata kunci: Effect Size, Visual Auditori Kinestetik

\section{Abstract}

There is no recent research that examines the results of research on the Visualization Auditory Kinesthetic learning model on science learning outcomes at the elementary school level. This study aims to analyze the influence of the Visual Auditory Kinesthetic (VAK) learning model on science learning outcomes in elementary schools. The method used is a meta-analysis of a narrative review or systematic review by analyzing the results of research that have been published nationally related to the use of the Visual Auditory Kinesthetic model of learning outcomes in science in elementary schools. The sample of analysis is five journals that have been published in the period 2013-2020, which discuss the writing of experiments using the Visual Auditory Kinesthetic model of science learning outcomes. The approach used is descriptive quantitative, namely calculating the effect size by identifying the mean, standard deviation, and variance of the t-test calculation. The writing instrument is a coding sheet that summarizes the data and journal information. Based on the results of the overall effect analysis, the average value of the influence is 3.67 , which means that it is in the large effect category. The analysis findings also show that the Visual Auditory Kinesthetic learning model provides an effective influence in terms of the area and the dependent variable as well as the learning media used. In each article that has been analyzed for the effect size, there are differences in the results of the Visual Auditory Kinesthetic learning model which is assisted by learning media, and those that are not assisted by learning media. learn science in elementary school.

Keywords: Effect Size, Visual Auditory Kinestheti

\section{INTRODUCTION}

IPA yang sering disebut juga dengan istilah pendidikan sains adalah IPA. IPA merupakan singkatan dari "Ilmu Pengetahuan Alam" yang merupakan terjemahan dari Bahasa Inggris "Natural Science". Natural berarti alamiah atau berhubungan dengan alam. Science berarti ilmu pengetahuan. Jadi menurut asal katanya, IPA berarti ilmu tentang alam atau ilmu yang mempelajari peristiwa-peristiwa di alam (Juniati \& Widiana, 2017; Khusniati et al., 2017; Paramitha \& Margunayasa, 2016). Pembelajaran IPA ada tiga dimensi yang harus ada yaitu, IPA sebagai produk, proses, dan sikap (Ana, 2019; Arifin et al., 2017;

$\begin{array}{lll}\text { History: } & & \text { Publisher: Undiksha Press } \\ \text { Received } & : \text { 26 Oktober } 2020 & \text { Licensed: This work is licensed under } \\ \text { Revised } & : 11 \text { Desember } 2020 & \text { a Creative Commons Attribution 3.0 License } \\ \text { Accepted } & : 26 \text { April } 2021 & \text { CC } \\ \text { Published } & : 1 \text { Mei } 2021 & \text { (C) }\end{array}$


Setiawan et al., 2017). Pembelajaran IPA tidak hanya mengajarkan tentang penguasaan fakta, konsep dan prinsip tentang alam tetapi juga mengajarkan tentang metode pemecahan masalah, melatih berpikir kritis, bersikap objektif, mengambil kesimpulan, serta dapat bekerja sama dengan orang lain (Arman et al., 2020; Prayogi et al., 2018). Model pembelajaran yang harus diberikan kepada siswa sekolah dasar adalah model pembelajaran yang dapat menyesuaikan dengan keadaan lingkungan ataupun keadaan siswa dikehidupan nyata masyarakat. Siswa semestinya diberi kesempatan untuk menggunakan alat-alat dan media pembelajaran yang ada di lingkungannya untuk diterapkan dalam kehidupan seharihari (Dewi \& Akhlis, 2016; Rahayuni, 2016).

Pembelajaran IPA sebaiknya dilakukan secara inkuiri artinya siswa harus berupaya mengekspor diri untuk mencari, menemukan serta menyelesaikan permasalahan yang diberikan oleh guru (Agustina, 2015; Suantara et al., 2019). Pembelajaran IPA di sekolah dasar adalah salah satu pembelajaran yang sangat penting, sehingga kompetensi pengetahuan IPA siswa diharapkan baik dan mencapai hasil yang diiginkan oleh kurikulum. Namun, kenyataan di lapangan yaitu hasil belajar IPA siswa yang rendah diindikasikan karena kurangnya penguasaan konsep IPA yang disebabkan oleh kesulitan peserta didik dalam merespon pembelajaran yang diberikan oleh guru. Beberapa temuan mengindikasikan penyebab kesulitan belajar IPA peserta didik Sekolah disebabkan oleh terlalu banyaknya istilah asing, materi pembelajaran yang terlalu padat sehingga siswa mau tidak mau harus menghafal materi, keterbatasan media pembelajaran yang membuat siswa kesulitan dalam memahami materi pembelajaran, guru yang cenderung mendominasi pembelajaran, penguasaan guru akan materi yang masih lemah, kurangnya kemampuan guru dalam memahami gaya belajar siswa, dan guru yang terlalu monoton dalam mengajar.

Peningkatan kualitas dan efektitivitas pembelajaran IPA telah dilakukan melalui berbagai upaya, salah satu dari upaya terebut adalah penggunaan model pembelajaran model Visualization Auditory Kinestetic (VAK). Model pembelajaran Visualization Auditory Kinestetic merupakan anak dari model pembelajaran Quantum yang berberinsip menjadikan suasana belajar menjadi lebih nyaman dan menjadikan kesuksesan bagi pelajar di masa depan (Elisa et al., 2019; Parbawa \& Sujana, 2018; Rahmawati, 2018). Model pembelaran Visualization Auditory Kinestetic merupakan model yang mengoptimalkan ketiga modalitas belajar. Tiga modalitas tersebut dikenal dengan gaya belajar. Gaya belajar merupakan bagaimana sesorang dapat mengeleloh, menerima, menyerap, serta mengatur informasi. Pada model pembelajaran Visualization Auditory Kinestetic, pembelajaran difokuskan pada pemberian pengalaman oleh guru kepada siswa untuk belajar secara langsung (direct experience) dan menyenangkan. Pengalaman belajar secara langsung dengan cara belajar dengan melihat (visual), belajar dengan mendengar (Auditory), dan belajar dengan gerak dan emosi (kinestethic).

Pembelajaran menggunakan model Visualization Auditory Kinestetic merupakan model pembelajaran yang efektif yang dapat mengarahkan siswa untuk dapat mengembangkan gaya belajar yang dimilikinya dan guru membantu siswa untuk dapat mengembangkan gaya belajar yang dimiliki oleh siswa dengan menyediakan media pembelajaran yang efektif yang dapat membantu siswa (Noorbaiti et al., 2018; Rukmana et al., 2018). Beberapa penelitian terdahulu menunjukan bahwa model pembelajaran Visualization Auditory Kinestetic memberikan pengaruh terhadap hasil belajar IPA. Hal tersebut dapat terlihat dari meningkatnya hasil belajar siswa sesudah siswa mendapatkan perlakuan dengan menggunkan model pembelajaran Visualization Auditory Kinestetic pada muatan pembelajaran IPA (Elisa et al., 2019; Parbawa \& Sujana, 2018; Rukmana et al., 2018). Namun saat ini belum adanya penelitian terbaru yang mengkaji hasil-hasil penelitian model pembelajaran Visualization Auditory Kinestetic terhadap hasil belajar IPA di tingkat sekolah dasar. Tujuan penelitian ini menganalisis besar pengaruh model pembelajaran 
Visualization Auditory Kinestetic berdasarkan data-data ataupun temuan yang sudah ada dari hasil penelitian sebelumnya yang nantinnya akan menghasilkan teori baru yang dapat dijadikan penguatan hasil penelitian sebelumnya.

\section{MATERIALS AND METHODS}

Penelitian ini merupakan penelitian library research dengan menggunakan pendekatan deskriptif kuantitaif (Glass dalam Surata et al., 2020). Penelitian library research ini akan mendeskripsikan data statistik dengan menggunakan metode meta-analisis. Penelitian ini menggunakan pustaka, buku ataupun jurnal sebagai sumber datanya. Peneliti akan mengambil beberapa penelitian yang memiliki satu topik atau tema yang sama dalam penelitian ini. Metode ini digunakan untuk meringkas, merangkum dan memperoleh intisari hasil temuan dari sejumlah penelitian. Meta-analisis dapat bersifat kuantitatif dan merupakan suatu analisis statistik untuk memperoleh serangkaian informasi yang berasal dari sejumlah data dari penelitian-penelitian sebelumnya. Data statistik yang dianalisis yaitu penelitian eksperimen tentang pengaruh model pembelajaran Visualization Auditory Kinestetic (VAK).

Subjek dari penelitian ini adalah artikel yang telah dipublikasikan secara nasional dengan kriteria yaitu 1) ditulis oleh peneliti umum maupun mahasiswa, 2) penelitian dilakukan di Indonesia, 3) penelitian dilakukan dalam rentan tahun 2013-2020,4) mengenai penelitian eksperimen tentang model pembelajaran Visualization Auditory Kinestetic (VAK terhadap hasil belajar IPA, 5) penelitian dilakukan pada jenjang pendidikan dasar 6) penelitian mencantumkan data-data hasil penelitian seperti mean, median, modus dan standar deviasi, 7) artikel dipublikasikan dalam jurnal yang terakreditasi sinta. Pengumpulan data dalam penelitian ini dilakukan dengan studi pustaka dengan kajian terhadap artikel yang berkaitan dengan topik penelitian. Pengumpulan data dengan mencari artikel yang relevan dengan topik yang akan diteliti dalam situs google scholar dengan kata kunci penelusuran yaitu pengaruh model pembelajaran Visualization Auditory Kinestetic (VAK) terhadap hasil belajar IPA siswa di sekolah dasar. Penelitian ini hanya menemukan lima artikel yang bertema pembelajaran Visualization Auditory Kinestetic (VAK ) terhadap hasil belajar IPA siswa SD. Artikel yang ditemukan telah memenuhi kriteria subjek penelitian yaitu ditulis oleh peneliti umum maupun mahasiswa, penelitian dilakukan di Indonesia, penelitian dilakukan dalam rentangan tahun 2013-2020, mengenai penelitian eksperimen tentang pengaruh model pembelajaran Visualization Auditory Kinestetic (VAK) terhadap hasil belajar IPA, penelitian dilakukan pada jenjang pendidikan dasar, penelitian mencantumkan data-data hasil penelitian seperti mean, median, modus dan standar deviasi, dan artikel dipublikasikan dalam jurnal yang terakreditasi.

\section{RESULTS AND DISCUSSION}

Penelitian-penelitian yang dianalisis berjumlah lima buah. Penelitian yang digunakan diambil dari berbagai artikel pada jurnal yang dipublikasikan secara nasional yang sesuai dengan kriteria yang telah ditentukan. Setelah dilakukan analisis terhadap artikel-artikel tersebut. Hasil analisis dari artikel-artikel yang tercantum dalam lampiran kemudian dihitung nilai effect size-nya, kemudian dikelompokan dalam kategori efek besar, sedang dan kecil. Data perhitungan dan pengelompokan tersebut dapat dilihat pada Tabel 1. Setiap tahun hasil penelitian di bidang pendidikan yang mengambil tema model pembelajaran Visual Auditorial Kinestetik dibukukan melalui laporan penelitian dan di publikasikan ke media berupa jurnal yang telah dilakukan sejak paruh pertama abad dua puluh sampai sekarang. Penelitian tersebut dapat berupa eksperimen, deskriptif, korelasi dan sebagaiannya. Data mengenai hasil penelitian model pembelajaran Visual Auditorial Kinestetik sangat banyak, tetapi penelitian 
lanjutan mengenai data-data tersebut belum banyak dilakukan. Sedangkan data-data penelitian model pembelajaran Visual Auditorial Kinestetik membutuhkan penelitian lanjutan untuk menilai dan mengevaluasi hasil penelitianmya, sehingga dapat dinilai dan menguatkan hasil penilain tersebut. Atas dasar tersebut, penelitian mencari nilai effect size pada penggunaan model pembelajaran Visual Auditorial Kinestetik dilakukan untuk menilai dan mengevaluasi penelitian-penelitian sebelumnya.

Tabel 1. Data Pengelompokan Effect size Secara Keseluruhan

\begin{tabular}{|c|c|c|c|c|c|c|c|}
\hline No & $\begin{array}{c}\text { Kode } \\
\text { Jurnal }\end{array}$ & $\begin{array}{c}\text { Jenjang } \\
\text { Pendidikan }\end{array}$ & Wilayah & $\begin{array}{l}\text { Variabel } \\
\text { Terikat }\end{array}$ & $\begin{array}{c}\text { Variabel } \\
\text { Bebas }\end{array}$ & $\begin{array}{c}\text { Nilai } \\
\text { Effect Size }\end{array}$ & Kategori \\
\hline 1 & A1 & SD & $\begin{array}{c}\text { Kab. } \\
\text { Buleleng }\end{array}$ & $\begin{array}{l}\text { Hasil } \\
\text { Belajar }\end{array}$ & $\begin{array}{c}\text { Model } \\
\text { pembelajaran }\end{array}$ & 0,95 & Besar \\
\hline 2 & A 2 & $\mathrm{SD}$ & $\begin{array}{c}\text { Kab. } \\
\text { Buleleng }\end{array}$ & IPA & $\begin{array}{c}\text { Visual } \\
\text { Auditorial }\end{array}$ & 0,66 & Sedang \\
\hline 3 & A3 & SD & $\begin{array}{c}\text { Kab. } \\
\text { Gianyar }\end{array}$ & & Kinestetik & 1,04 & Besar \\
\hline 4 & A4 & SD & $\begin{array}{c}\text { Kab. } \\
\text { Denpasar }\end{array}$ & & & 0.8 & Besar \\
\hline 5 & A5 & SD & $\begin{array}{c}\text { Kab. } \\
\text { Badung }\end{array}$ & & & 1,14 & Besar \\
\hline & \multicolumn{5}{|c|}{ Rerata Effect Size Secara Keseluruhan } & 3,67 & Besar \\
\hline
\end{tabular}

Artikel yang telah diperoleh yang membahas tentang pengaruh model pembelajaran Visual Auditorial Kinestetik pada pembelajaran IPA di sekolah dasar diambil dari rentangan waktu penelitian 2013-2020. Data tersebut peneliti dapatkan dari hasil penelurusan di berbagai jurnal nasional terakreditasi. Setelah dilakukan analisis menyeluruh dari jurnal tersebut hanya didapatkan lima yang telah dianalisis, kemudian dikelompokan dan dihitung dengan menggunakan perhitungan effect size. Pengelompokan hasil perhitungan effect size ke dalam kelompok efek besar, sedang dan kecil mengacu pada kriteria Gravetter dan Wallnau. Hasil analisis mengungkapkan bahwa ada empat artikel yang memiliki effect size yang besar dan satu artikel masuk dalam kategori effect size sedang dan secara keseluruhan rata-rata effect size modol pembelajaran Visual Auditorial Kinestetik yang dikaitkan dengan penelitian-penelitian yang bersifat eksperimen yang telah dianalisis mencapai 3,67 dan masuk dalam kategori efek yang besar. Hal ini membuktikan bahwa pembelajaran dengan menggunakan model pembelajaran Visual Auditorial Kinestetik memiliki pengaruh yang besar dalam pembelajaran IPA di sekolah dasar. Sebelum menentukan effect size secara keseluruhan, ditentukan dahulu nilai effect size untuk setiap artikel kemudian nilai statistiknya didata dan dianalisi. Diantaranya yaitu hasil nilai rerata kelompok eksperimen $\left(x_{1}\right)$. Nilai rerarata kelompok kontrol $\left(x_{2}\right)$, jumlah sampel kelompok eksperimen $\left(n_{1}\right)$, jumlah sampel kelompok kontrol $\left(n_{2}\right)$, varians kelompok eksperimen $\left(s_{1}^{2}\right)$, dan varians kelompok kontrol $\left(s_{2}^{2}\right)$. Setelah semua nilai statistik didapatkan dari setiap artikel, selanjutnya dihitung nilainya dengan menggunakan rumus effect size.

Berdasarkan hasil analisis lima buah artikel yang telah dilakukan, terdapat perbedaan besar hasil effect size yang diperoleh. Artikel pertama yang berjudul "Pengaruh Model Pembelajaran VAK (Visual, Auditorial, Kinestetik) Bermediakan Lingkungan Sekolah Terhadap Hasil Belajar IPA" oleh (Parwati et al., 2018) diperoleh nilai rerata kelompok eksperimen $\left(x_{1}\right)$ sebesar 25,14, Nilai rerarata kelompok kontrol $\left(x_{2}\right)$ sebesar 19,91, jumlah 
sampel kelompok eksperimen $\left(n_{1)}\right.$ sebesar 21, jumlah sampel kelompok kontrol $\left(n_{2}\right)$ sebesar 23, varians kelompok eksperimen $\left(s_{1}^{2}\right)$ sebesar 4,30, varians kelompok kontrol $\left(s_{2}^{2}\right)$ sebesar 4,15. Kemudian dianalisis dengan menggunakan rumus effect size dan diperoleh hasil effect size sebesar 1,14 dan termasuk dalam kategori effect size yang besar hal ini dilihat dari kategori nilai effect size $0,8>\mathrm{d}$.

Artikel kedua yang berjudul "Pengaruh Model Pembelajaran Visual Auditori Kinestetik Berbantuan Audio Visual Terhadap Hasil Belajar IPA kelas V" oleh (Suryantini et al., 2017), diperoleh nilai rerata kelompok eksperimen $\left(x_{1}\right)$ sebesar 84,13 Nilai rerarata kelompok kontrol $\left(x_{2}\right)$ sebesar 76,08, jumlah sampel kelompok eksperimen $\left(n_{1}\right)$ sebesar 48, jumlah sampel kelompok kontrol $\left(n_{2}\right)$ sebesar 38, varians kelompok eksperimen $\left(s_{1}^{2}\right)$ sebesar 10,51, varians kelompok kontrol $\left(s_{2}^{2}\right)$ sebesar 9,52. Kemudian dianalisis dengan menggunakan rumus effect size dan diperoleh hasil effect size sebesar 0.8 dan termasuk dalam kategori effect size yang besar hal ini dilihat dari kategori nilai effect size 0,8>d. Artikel ketiga berjudul "Pengaruh Model Pembelajaran VAK Berbantuan Lingkungan Terhadap Hasil Belajar IPA kelas V SD Gugus Mas" oleh (Adnyani et al., 2014) diperoleh nilai rerata kelompok eksperimen $\left(x_{1}\right)$ sebesar 71,35 Nilai rerarata kelompok kontrol $\left(x_{2}\right)$ sebesar 60,75 jumlah sampel kelompok eksperimen $\left(n_{1}\right)$ sebesar 48 , jumlah sampel kelompok kontrol $\left(n_{2}\right)$ sebesar 42, varians kelompok eksperimen $\left(s_{1}^{2}\right)$ sebesar 10,31, varians kelompok kontrol $\left(s_{2}^{2}\right)$ sebesar 10,054. Kemudian dianalisis dengan menggunakan rumus effect size dan diperoleh hasil effect size sebesar 1,04 dan termasuk dalam kategori effect size yang besar hal ini dilihat dari kategori nilai effect size $0,8>\mathrm{d}$.

Artikel keempat berjudul "Pengaruh Model Pembelajaran Kuantum Tipe VAK (Visual, Auditory, Kinesthetic) terhadap Hasil Belajar IPA SISWA Kelas V SD Negeri 2 Sesetan" oleh (Ariastini et al., 2013) diperoleh nilai rerata kelompok eksperimen $\left(x_{1}\right)$ sebesar 77,72 Nilai rerarata kelompok kontrol $\left(x_{2}\right)$ sebesar 69,75 jumlah sampel kelompok eksperimen $\left(n_{1}\right)$ sebesar 44, jumlah sampel kelompok kontrol $\left(n_{2}\right)$ sebesar 40, varians kelompok eksperimen $\left(s_{1}^{2}\right)$ sebesar 11,12 . varians kelompok kontrol $\left(s_{2}^{2}\right)$ sebesar 12,92. Kemudian dianalisis dengan menggunakan rumus effect size dan diperoleh hasil effect size sebesar 0,66 dan termasuk dalam kategori effect size yang sedang hal ini dilihat dari kategori nilai effect size $0,8>\mathrm{d}>0.2$.

Artikel kelima "Pengaruh Model Pembelajaran Quantum Tipe VAK Berbantuan Media Magix Box Terhadap Hasil Belajar IPA kelas IV SD” oleh (Pebriani et al., 2013) diperoleh nilai rerata kelompok eksperimen $\left(x_{1}\right)$ sebesar 20,86 Nilai rerarata kelompok kontrol $\left(x_{2}\right)$ sebesar 16,96 jumlah sampel kelompok eksperimen $\left(n_{1}\right)$ sebesar 29, jumlah sampel kelompok kontrol $\left(n_{2}\right)$ sebesar 28 , varians kelompok eksperimen $\left(s_{1}^{2}\right)$ sebesar 4,05 , varians kelompok kontrol $\left(s_{2}^{2}\right)$ sebesar 4,14 . Kemudian dianalisis dengan menggunakan rumus effect size dan diperoleh hasil effect size sebesar 1,14 dan termasuk dalam kategori effect size yang besar hal ini dilihat dari kategori nilai effect size $0,8>\mathrm{d}$.

Secara keseluruhan hasil analisis model pembelajaran Visual, Auditorial, Kinestetik terhadap hasil belajar IPA masuk dalam kategori effect size yang besar. Sehingga hasil analisis tersebut menguatkan bahwa model pembelajaran Visual, Auditorial, Kinestetik yang telah diterapkan memiliki pengaruh yang besar terhadap hasil belajar IPA siswa di SD. Hasil effect size yang besar juga depengaruhi oleh penggunaan media pembelajaran yang digunakan pada model pembelajaran Visual Auditori Kinestetik. Media pembelajaran merupakan salah satu sumber belajar yang membantu guru dalam menyampaikan materi ajar. Penggunaan media pembelajaran dalam proses pembelajaran sangatlah penting karena dengan media pembelajaran siswa akan lebih mudah memahami serta lebih cepat menangkap 
informasi yang disampaikan oleh guru. Penggunaan Media pembelajaran juga akan memacu semangat siswa dalam proses belajar, untuk itu penting bagi guru sebelum melakukan pembelajaran guru harus mempersiapkan media pembelajaran dengan baik sehingga proses belajar mengajar dapat terarah dengan baik dan tujuan pembelajaran dapat tercapai secara maksimal.

Lima artikel yang telah dicari hasil effect sizenya empat diantaranya menggunakan media pembelajaran dan satu artikel tidak meggunakan media pembelajaran. Penelitian yang dilakukan oleh (Pebriani et al., 2013) menggunakan media "Magix Box" .Penelitian ini tergolong dalam effect size yang besar yaitu 0,95. Penelitian yang dilakukan oleh (Ariastini et al., 2013) tidak menggunakan media pembelajaran dan hasil effect size dalam peneltian ini tergolong dalam kategori sedang yaitu 0,66. Penelitian yang dilakukan oleh (Adnyani et al., 2014) menggunakan media lingkungan dan hasil effect size dalam penelitian ini yaitu tergolong effect size besar yaitu 1,04. Penelitian yang dilakukan oleh (Suryantini et al., 2017) menggunakan media audio visual dengan hasil effect size tergolong besar yaitu 0,8 dan penelitian yang dilakukan oleh (Parwati et al., 2018) menggunakan media lingkungan sekolah. Hal ini membuktikan bahwa penggunaan media dalam model pembelajaran pada saat proses pembelajaran memberikan dampak yang positif.

Perbedaan hasil analisis uji effect size yang diperoleh, menandakan bahwa jumlah sampel yang digunakan dalam penelitian sangat berperan dalam menentukan pengaruh dari model yang diterapkan. Semakin banyak sampel yang digunakan dalam penelitian, maka semakin akurat pula data yang didapatkan, hal tersebut menjadi penentu keberhasilan model pembelajaran yang digunakan, namun meskipun dari keempat wilayah tersebut didapatkan hasil analisis yang berbeda-beda tentunya dengan jumlah sampel yang berbeda pula namun angka yang dihasilkan setelah dianalisis menunjukan bahwa angka-angka tersebut masuk ke dalam kategori besar. Hal ini membuktikan bahwa model pembelajaran Visual, Auditorial, Kinestetik memberi pengaruh yang besar terhadap hasil belajar IPA di SD. Hasil penelitian ini akan menjadi bahan referensi baik bagi guru maupun peneliti lain yang akan melakukan penelitian mengenai pengaruh model pembelajaran Visual, Auditorial, Kinestetik terhadap hasil belajar siswa IPA di SD. Penelitian ini bisa dijadikan dasar bagi guru dalam menggunakan model pembelajaran Visual, Auditorial, Kinestetik, khususnya dalam penyampaian materi pelajaran dengan tepat. Model pembelajaran Visual, Auditorial, Kinestetik dapat berdampak baik bagi pemahaman siswa dalam pembelajaran, sehingga siswa menjadi lebih aktif dalam pembelajaran karena siswa lebih mudah dalam memahami materi, sehingga tujuan pembelajaran dapat tercapai dengan baik

\section{CONCLUSION}

Pengaruh model pembelajaran Visualization Auditory Kinestetic secara keseluruhan mampu meningkatkan hasil belajar IPA siswa di SD pada kelompok eksperimen dengan effect size dalam katagori besar. Hal tersebut menunjukan bahwa model pembelajaran Visualization Auditory Kinestetic memberikan pengaruh yang efektif dalam pembelajaran dan patut diterapkan dalam meningkatkan hasil belajar IPA di SD. Model pembelajaran Visualization Auditory Kinestetic berpengaruh terhadap hasil belajar IPA siswa, karena menciptakan suatu metode pembelajaran yang menarik dan menyenangkan, sehingga interaksi siswa dengan siswa, maupun guru dengan guru terjalin dengan baik. Model pembelajaran ini dapat menumbuhkan rasa percaya diri, motivasi, dan minat pada diri siswa sehingga orang tua mengetahui perkembangan anaknya. 


\section{REFERENCES}

Adnyani, N. L. S., Renda, N. T., \& Kusmariyatni, N. (2014). Pengaruh Model Vak Berbantuan Lingkungan Terhadap Hasil Belajar Ipa Siswa Kelas V Sd Gugus Mas. Mimbar PGSD Undiksha, 2(1). http://dx.doi.org/10.23887/jjpgsd.v2i1.3593.

Agustina, R. L. (2015). Upaya meningkatkan hasil belajar IPA siswa kelas IV menggunakan model STAD dan NHT. Journal of EST, 1(3), 31-38. https://doi.org/10.33557/jedukasi.v12i2.787.

Ana, N. Y. (2019). Penggunaan Model Pembelajaran Discovery Learning Dalam Peningkatan Hasil Belajaran Siswa Di Sekolah Dasar. Pedagogi: Jurnal Ilmu Pendidikan, 18(2), 56. https://doi.org/10.24036/fip.100.v18i2.318.000-000.

Ariastini, N. L. P., Suardika, W. R., \& Manuaba, I. . S. (2013). Pengaruh Model Pembelajaran Kuantum Tipe VAK (Visual, Auditory, Kinesthetic) terhadap Hasil Belajar IPA SISWA Kelas V SD Negeri 2 Sesetan. MIMBAR PGSD Undiksha, 1(1). http://dx.doi.org/10.23887/jjpgsd.v1i1.1185.

Arifin, M. Y., Kirana, T., \& Widodo, W. (2017). Pembelajaran Inkuiri Terbimbing Untuk Meningkatkan Kemampuan Bernalar Siswa Kelas Vi Berbantuan Media Buku Pop Up. Jurnal Penelitian Pendidikan IPA, 2(1), 6-14. http://dx.doi.org/10.26740/jppipa.v2n1.p6-10.

Arman, A., Annisa, M., \& Kartini, K. (2020). Pengembangan Perangkat Pembelajaran Ipa Berkarakter Berbasis Integrasi Model Pembelajaran Problem Based Learning Dan Keterampilan Proses Sains. LENSA (Lentera Sains): Jurnal Pendidikan IPA, 10(1), 110. https://doi.org/10.24929/lensa.v10i1.90.

Dewi, N. R., \& Akhlis, I. (2016). Pengembangan perangkat pembelajaran IPA berbasis pendidikan multikultural menggunakan permainan untuk mengembangkan karakter siswa. USEJ - Unnes Science Education Journal, 5(1). https://doi.org/10.15294/usej.v5i1.9569.

Elisa, T. D., Hermita, N., \& Noviana, E. (2019). Penerapan Model Pembelajaran Vak (Visualization, Auditory, Dan Kinestethic) Terhadap Hasil Belajar Ipa Peserta Didik Kelas Iv Sd Negeri 147 Pekanbaru. Jurnal Dinamika Pendidikan Dasar, 11(1), 1926. http://dx.doi.org/10.30595/dinamika.v11i1.5981.

Juniati, N. W., \& Widiana, I. W. (2017). Penerapan model pembelajaran inkuiri untuk meningkatkan hasil belajar IPA. Jurnal Ilmiah Sekolah Dasar, 1(2), 20-29. http://dx.doi.org/10.23887/jisd.v1i1.10126.

Khusniati, M., Parmin, \& Sudarmin. (2017). Local wisdom-based science learning model through reconstruction of indigenous science to improve student's conservationist character. Journal of Turkish Science Education, 14(3), 16-23. https://doi.org/10.12973/tused.10202a.

Noorbaiti, R., Fajriah, N., \& Sukmawati, R. A. (2018). Implementasi Model Pembelajaran Visual-Auditori-Kinestetik (VAK) pada Mata Pelajaran Matematika di Kelas VII E MTsN Mulawarman Banjarmasin. EDU-MAT: Jurnal Pendidikan Matematika, 6(1), 108-116. https://doi.org/10.20527/edumat.v6i1.5130.

Paramitha, I. D. A. A., \& Margunayasa, I. G. (2016). Pengaruh model inkuiri terbimbing, gaya kognitif, dan motivasi berprestasi terhadap pemahaman konsep IPA siswa kelas V SD. Jurnal Pendidikan Dan Pengajaran, 49(2), 80. https://doi.org/10.23887/jppundiksha.v49i2.9012.

Parbawa, I. G. N. M. A., \& Sujana, I. W. (2018). Pengaruh Model Pembelajaran Visual Auditory Kinestetik dan Motivasi Belajar terhadap Kompetensi Pengetahuan IPS Siswa Kelas IV. Jurnal Ilmiah Sekolah Dasar, 2(1), 68-72. http://dx.doi.org/10.23887/jisd.v2i1.13896.

Parwati, I. A. K. C., Japa, I. G. N., \& Mahadewi, L. P. P. (2018). Pengaruh Model 
Pembelajaran VAK (Visual, Auditorial, Kinestetik) Bermediakan Lingkungan Sekolah Terhadap Hasil Belajar IPA. Jurnal Pendagogi Dan Pembelajaran, 1(3), 145-153. http://dx.doi.org/10.23887/jp2.v1i3.19342.

Pebriani, N. P. A., Tegeh, I. M., \& Pudjawan, K. (2013). Pengaruh Model Pembelajaran Quantum Tipe VAK Berbantuan Media Magic Box Terhadap Hasil Belajar IPA Kelas IV SD. Mimbar PGSD Undiksha, 1(1). http://dx.doi.org/10.23887/jjpgsd.v1i1.730.

Prayogi, S., Yuanita, L., \& Wasis, L. (2018). Critical inquiry based learning: A model of learning to promote critical thinking among prospective teachers of physic. Journal of Turkish Science Education, 15(1), 43-56. https://doi.org/10.12973/tused.10220a.

Rahayuni, G. (2016). Hubungan Keterampilan Berpikir Kritis Dan Literasi Sains Pada Pembelajaran Ipa Terpadu Dengan Model Pbm Dan Stm. Jurnal Penelitian Dan Pembelajaran IPA, 2(2), 131-146. https://doi.org/10.30870/jppi.v2i2.926.

Rahmawati, N. K. (2018). Penerapan Model Pembelajaran Matematika Menggunakan Model Savi Dan Vak Pada Materi Himpunan Terhadap Prestasi Belajar Siswa Kelas VII. Delta: Jurnal Ilmiah Pendidikan Matematika, 5(2), 21-24. https://doi.org/10.31941/delta.v5i2.549.

Rukmana, W., Hardjono, N., \& Aryana, A. (2018). Peningkatan Aktivitas dan Hasil Belajar dengan Model Pembelajaran VAK Berbantuan Media Tongkat Tokoh. International Journal of Elementary Education, 2(3), 156-164. http://dx.doi.org/10.23887/ijee.v2i3.15954.

Setiawan, B., Innatesari, D. K., Sabtiawan, W. B., \& Sudarmin, S. (2017). The development of local wisdom-based natural science module to improve science literation of students. Jurnal Pendidikan IPA Indonesia, 6(1), 49-54. https://doi.org/10.15294/jpii.v6i1.9595.

Suantara, I. K. T., Ganing, N. N., \& Wulandari, I. G. A. A. (2019). Pengaruh Model Pembelajaran Think Pair Share Berbantuan Media TTS terhadap Kompetensi Pengetahuan IPA. Jurnal Ilmiah Sekolah Dasar, 3(4), 473. https://doi.org/10.23887/jisd.v3i4.21783.

Surata, I. K., Sudiana, I. M., \& Sudirgayasa, I. G. (2020). Meta-Analisis Media Pembelajaran pada Pembelajaran Biologi I Ketut Surata I Made Sudiana I Gede Sudirgayasa. Journal of Education Technology, 4(1), 22-27. https://doi.org/http://dx.doi.org/10.23887/jet.v4i1.24079.

Suryantini, N. W. N., Wiarta, I. W., \& Manuaba, I. B. S. (2017). Pengaruh Model Pembelajaran Visual Auditori Kinestetik Berbantuan Media Audio Visual Terhadap Kompetensi Pengetahuan Ipa Siswa Kelas V. Mimbar PGSD Undiksha, 5(2). http://dx.doi.org/10.23887/jjpgsd.v5i2.10636. 